\title{
STAT1 wt Allele
}

National Cancer Institute

\section{Source}

National Cancer Institute. STAT1 wt Allele. NCI Thesaurus. Code C52151.

Human STAT 1 wild-type allele is located within 2q32.2-q32.3 and is approximately $45 \mathrm{~kb}$ in length. This allele, which encodes signal transducer and activator of transcription 1alpha/beta protein, plays a role in cellular viability and transcriptional modulation of both cytokine and growth factor responsive genes. 